\title{
O controle de constitucionalidade das políticas públicas no Brasil e a importação de modelos de controle de constitucionalidade pela Constituição de 1988
}

\author{
The Judicial Review of the public policies in Brazil \\ and models adopted by Brazilian's Constitution
}

\section{Hector Cury Soares}

Doutorando em Direito pela Universidade Federal do Rio Grande do Sul (UFRGS), Mestre em Direito pela Universidade do Vale do Rio dos Sinos (UNISINOS), professor assistente da Universidade Federal do Pampa (UNIPAMPA), na área de Administração Pública, membro do Grupo Transdisciplinar em Pesquisa Jurídica (GTJS), responsável pela coordenação da linha de pesquisa "Políticas Públicas", Porto Alegre, RS - Brasil, e-mail: hectorcury@gmail.com

\section{Resumo}

O presente artigo tem como objetivos centrais apresentar o modelo de controle constitucionalidade adotado pela Constituição brasileira, bem como a origem desses modelos e os reflexos (ou possíveis) no controle da constitucionalidade. Em especial o controle da constitucionalidade das políticas públicas no Brasil. Da mesma forma, busca mostrar os possíveis limites que possam ser estabelecidos e os efeitos que, porventura, possa ter esse 
controle, em relação às políticas públicas. Por conseguinte, estabelece-se uma linha que permita identificar os principais problemas da importação desses modelos e tracejar critérios que possam ser universalizáveis ao controle das políticas públicas no Brasil, carência evidenciada no direito administrativo.

Palavras-chave: Direito administrativo. Administração pública. Políticas públicas.

\section{Abstract}

This article aims to present the central control model constitutionality adopted by the Brazilian Constitution, as well as the origin of these models and reflections (or possibles) to control the constitutionality of public policies in Brazil. Similarly, it intends to show the possible limits that may be established and the effect that, perchance, to have this control, in relation to public policies. Therefore, establishing a line identifying the key problems of importation of these models and dashed criteria that may be universalizable the control of public policy in Brazil, grace evidenced in Administrative law.

Keywords: Administrative law. Public administration. Policies.

\section{Introdução}

Se, por um lado, a Constituição Federal (CF) de 1988 deu ao Supremo Tribunal Federal a condição de guarda da Constituição (HECK 2002, 2008), por outro criou uma série de instrumentos que possibilitassem o acesso ao Supremo. A tarefa de guarda da Constituição está regulada no art. 102, caput. Também, regula o direito de petição na ação de inconstitucionalidade, a qual se encontra regulada no art. 102, I, CF. Além disso, por meio da Emenda Constitucional n. 3 (EC), introduziu-se no ordenamento jurídico brasileiro a ação direta de inconstitucionalidade. Ainda com base na citada emenda, criou-se a arguição de descumprimento de preceito fundamental, prevista no art. 102, parágrafo segundo, da CF. 
Enquanto a arguição de descumprimento de preceito fundamental foi regulada pela Lei 9.882, de 3 de dezembro de 1999, a ação direta de constitucionalidade e ação direta de inconstitucionalidade foram reguladas pela Lei 9.868 de 10 de novembro de 1999. Essas ações tratam do controle quando a questão principal é inconstitucionalidade/constitucionalidade da lei, que é objeto do procedimento. Contudo, não se esgotam aí as possibilidades de controle de constitucionalidade no Brasil, pois há ainda o chamado controle difuso. Nesse caso, há um litígio jurídico que tem como objeto a conformidade ao direito de um ato (HECK, 2002). ${ }^{1}$

Cada um desses instrumentos distintos foi objeto de importação de outro ordenamento jurídico, muitas vezes importação que é feita de forma inadequada, causando problemas na utilização desses instrumentos de controle, que perdem o seu sentido original e, portanto, a sua funcionalidade. De tal sorte, observou-se a necessidade de fazer um estudo voltado a perceber quais as origens dessas formas de controle e, de igual modo, como é a sua utilização no ordenamento jurídico brasileiro. Com isso, é possível pensar o futuro do controle de constitucionalidade de leis e como o Supremo Tribunal Federal tem utilizado esse controle, se há algum tipo de adequação ou mesmo conformação no ordenamento jurídico pátrio.

Para verificar a questão ligada à utilização dos instrumentos, o controle de constitucionalidade das políticas públicas, face ao tratamento dado no Brasil, afeiçoa-se como um campo interessante à verificação do objeto de análise - mormente a realização de audiências públicas, pelo Supremo Tribunal Federal, relativas às ações afirmativas e cotas nas universidades e às políticas públicas de saúde. Dessa forma, há uma atenção maior a como o STF realiza esse controle e dos limites a esse controle.

Em decorrência disso a pesquisa fragmenta-se em três partes: a primeira parte reserva-se a analisar os instrumentos de controle de constitucionalidade adotados pela Constituição Federal de 1988; na segunda parte, verificar como e quando se dá essa importação, bem como a sua

1 HECK, L. A., O controle normativo no direito constitucional brasileiro. Revista dos Tribunais, v. 800, p. 58 , jun. 2002. (e nota n. 1 ) 
adequação ao ordenamento jurídico brasileiro; e ao fim, observar a relação do Supremo Tribunal Federal e o controle de políticas públicas no Brasil. Ao fim, segue-se da conclusão.

\section{O controle de constitucionalidade e o desenvolvimento histórico do controle de constitucionalidade no Brasil}

O controle de constitucionalidade das leis pelos tribunais é uma criação do final do século XIX no Brasil. A Constituição de 1824 (Constituição do Império) não continha dispositivos legais acerca do controle da validade das normas jurídicas pelos tribunais, portanto cabia à Assembleia Geral velar pela guarda da Constituição, conforme o art. 15, IX da Constituição do Império (BRASIL, 2010a). ${ }^{2}$ Segundo Heck, esse dispositivo era complementado pelo art. 173 da mesma Constituição (BRASIL, 2010a), ${ }^{3}$ que indicava a competência da Assembleia Geral para verificar a observância da Constituição, no início de suas sessões. Também não se pode perder de vista a presença do Poder Moderador, no art. $98^{4} \mathrm{da}$ Constituição do Império (BRASIL, 2010a; HECK, 2002).

O modelo adotado pela Constituição de 1891, após a proclamação da República em 15 de novembro de 1889, é o norte-americano. Com isso, introduz-se no Brasil o controle difuso presente no art. 59, $\S 1^{\circ}$ da Constituição (BRASIL, 2010b), ${ }^{5}$ dispositivo que já estava presente na

2 Art. 15. E' da attribuição da Assembléa Geral: [...] IX. Velar na guarda da Constituição, e promover o bem geral do Nação.

3 Art. 173. A Assembléa Geral no principio das suas Sessões examinará, se a Constituição Politica do Estado tem sido exactamente observada, para prover, como fôr justo.

4 Art. 98. O Poder Moderador é a chave de toda a organisação Politica, e é delegado privativamente ao Imperador, como Chefe Supremo da Nação, e seu Primeiro Representante, para que incessantemente vele sobre a manutenção da Independencia, equilibrio, e harmonia dos mais Poderes Politicos.

5 Art 59 - Ao Supremo Tribunal Federal compete: [...] § 10 - Das sentenças das Justiças dos Estados, em última instância, haverá recurso para o Supremo Tribunal Federal: a) quando se questionar sobre a validade, ou a aplicação de tratados e leis federais, e a decisão do Tribunal do Estado for 
Constituição provisória de 1890, no art. 58, § 1º. A Constituição de 1934 apenas deu continuidade ao desenvolvimento do controle associando à palavra 'recurso' o adjetivo 'extraordinário', disposição contida no art. 59, $\S 1^{\circ}$ da Constituição de 1891, reproduzida no art. 76, inc. III da Constituição de 1934 (BRASIL, 2010c). ${ }^{6}$ Ademais, introduz algumas modificações, relatadas por Heck:

a) a declaração de inconstitucionalidade só poderia se dar por maioria absoluta de votos dos juízes dos tribunais (art. 179); ${ }^{7}$

b) a suspensão, por parte do Senado Federal, da execução de lei ou ato declarado inconstitucional (art. 91, inc. IV) ${ }^{8}$

c) a introdução da representação interventiva do Procurador Geral da República (art. 12, § 2º (BRASIL, 2010c; HECK, 2002). ${ }^{9}$

contra ela; b) quando se contestar a validade de leis ou de atos dos Governos dos Estados em face da Constituição, ou das leis federais, e a decisão do Tribunal do Estado considerar válidos esses atos, ou essas leis impugnadas.

6 Art 76 - À Corte Suprema compete: III - em recurso extraordinário, as causas decididas pelas Justiças locais em única ou última instância: a) quando a decisão for contra literal disposição de tratado ou lei federal, sobre cuja aplicação se haja questionado; b) quando se questionar sobre a vigência ou validade de lei federal em face da Constituição, e a decisão do Tribunal local negar aplicação à lei impugnada; c) quando se contestar a validade de lei ou ato dos Governos locais em face da Constituição, ou de lei federal, e a decisão do Tribunal local julgar válido o ato ou a lei impugnada; d) quando ocorrer diversidade de interpretação definitiva da lei federal entre Cortes de Apelação de Estados diferentes, inclusive do Distrito Federal ou dos Territórios, ou entre um deste Tribunais e a Corte Suprema, ou outro Tribunal federal.

7 Art 179 - Só por maioria absoluta de votos da totalidade dos seus Juízes, poderão os Tribunais declarar a inconstitucionalidade de lei ou ato do Poder Público.

8 Art 91 - Compete ao Senado Federal: IV - suspender a execução, no todo ou em parte, de qualquer lei ou ato, deliberação ou regulamento, quando hajam sido declarados inconstitucionais pelo Poder Judiciário.

9 Art 12 - A União não intervirá em negócios peculiares aos Estados, salvo: $V$ - para assegurar a observância dos princípios constitucionais especificados nas letras $a$ a $h$, do art. 7o, n. l, e a execução das leis federais; § 20 - Ocorrendo o primeiro caso do $n$. V, a intervenção só se efetuará depois que a Corte Suprema, mediante provocação do Procurador-Geral da República, tomar conhecimento da lei que a tenha decretado e Ihe declarar a constitucionalidade. 
Com a Constituição de 1937 opera-se uma restrição ao controle de constitucionalidade. Ela acolhe o art. 179 da Constituição de 1934, mas substitui a expressão 'poder público' por 'ato do presidente da República' (art. 96, caput da Constituição de 1937). A cooperação com o Senado Federal é suprimida e, em seu lugar, é colocado Parlamento ou presidente da República. Por outro lado, a representação interventiva não recebeu guarida na Constituição de 1937 (HECK, 2002). A ampliação do controle veio com a Constituição de 1946, na qual o controle difuso tinha sua previsão no art. 101, inc. III (BRASIL, 2010d). ${ }^{10}$ A regulação prevista no art. 179 da Constituição de 1934 foi acolhida no art. 200 da Constituição de 1946. O previsto no art. 91, IV estava presente no art. 64 da Constituição de 1946. A grande inovação da Constituição de 1946 veio com a Emenda Constitucional (EC) n. 16, de 6 de dezembro de 1956, que introduziu o controle concentrado direto no direito constitucional brasileiro. A modificação se deu no art. 101, inc. I, alínea "k", que dizia: "a representação contra inconstitucionalidade de lei ou ato de natureza normativa federal ou estadual, encaminhada pelo Procurador-Geral da República" deveria ser julgada pelo Supremo Tribunal Federal (HECK, 2002, p. 60).

Com a Constituição de 1967, que entrou em vigor no dia 15 de março de 1967, o controle difuso, regulado no seu art. 114, III. Quanto à maioria absoluta de votos para declarar a inconstitucionalidade (art. 179 da Constituição de 1934 e art. 200 da Constituição de 1946) foi acolhida no art. 111. Quanto à prescrição prevista no art. 91, IV, da Constituição de 1934 e art. 64 da Constituição de 1946, relativa à suspensão de execução de lei ou ato declarado inconstitucional, estava presente no art. 45, IV, da Constituição de 1967. No tocante à representação interventiva do procurador-geral da República, o art. 11, § $1^{\circ}$ da Constituição de 1967 contemplou essa possibilidade.

${ }^{10}$ Art 101 - Ao Supremo Tribunal Federal compete: III - julgar em recurso extraordinário as causas decididas em única ou última instância por outros Tribunais ou Juízes: c) quando se contestar a validade de lei ou ato de governo local em face desta Constituição ou de lei federal, e a decisão recorrida julgar válida a lei ou o ato. 
Com a Emenda Constitucional n. 1, de 17 de outubro de 1969, praticamente cria-se uma nova Constituição. No art. 119, III, ficou previsto o controle difuso. A questão atinente ao voto da maioria nos tribunais para a declaração de inconstitucionalidade (art. 179 da Constituição de 1934, art. 200 da Constituição de 1946 e art. 111 da Constituição de 1967), inicialmente acolhido pelo art. 116 com a EC n. 1/69, recebeu uma modificação com a EC n. 7/77 (BRASIL, 2010e). ${ }^{11}$ Por sua vez, o art. 42, VII, incorporou as disposições previstas no art. 91, IV, da Constituição de 1934 e no art. 45, IV, da Constituição de 1967 (suspensão pelo Senado Federal da execução de ato ou de lei declarado inconstitucional). Ademais, o controle concentrado de constitucionalidade tinha sua previsão no art. 119, inc. I, alínea "l"12 (BRASIL, 2010e) com uma nova formulação (HECK, 2002).

Por fim, a Constituição de 1988 estipulou o controle por meio da ação direta de inconstitucionalidade no art. 102, inc. I, alínea "a" (BRASIL, 2010f), ${ }^{13}$ que, por oportunidade da Emenda Constitucional n. 3, de 17 de março de 1993, introduziu ao lado da ação direta de inconstitucionalidade (ADin) a ação declaratória de constitucionalidade (ADC). Por meio da citada emenda constitucional, também foi incluída a arguição de descumprimento de preceito fundamental (ADPF) presente no art. 102, § $1^{\circ}$ da Constituição de 1988 (BRASIL, 2010f). ${ }^{14}$ Em relação ao controle de constitucionalidade difuso, no art. 102, inc. III, alíneas “a”, "b”, “c” e

${ }^{11}$ Art. 116. Somente pelo voto da maioria absoluta de seus membros ou dos membros do respectivo órgão especial (Artigo 144, V), poderão os Tribunais declarar a inconstitucionalidade de lei ou ato normativo do Poder Público.

12 Art. 119. Compete ao Supremo Tribunal Federal: I - processar e julgar originariamente; I) a representação do Procurador-Geral da República, por inconstitucionalidade ou para interpretação de lei ou ato normativo federal ou estadual; (Redação dada pela Emenda Constitucional n. 7, de 1977).

${ }^{13}$ Art. 102. Compete ao Supremo Tribunal Federal, precipuamente, a guarda da Constituição, cabendo-Ihe: a) a ação direta de inconstitucionalidade de lei ou ato normativo federal ou estadual; Com a EC n. 3/93: a) a ação direta de inconstitucionalidade de lei ou ato normativo federal ou estadual e a ação declaratória de constitucionalidade de lei ou ato normativo federal.

${ }^{14}$ Art. 102. Compete ao Supremo Tribunal Federal, precipuamente, a guarda da Constituição, cabendo-lhe: § 1.․ A arguição de descumprimento de preceito fundamental, decorrente desta Constituição, será apreciada pelo Supremo Tribunal Federal, na forma da lei. 
“d” (BRASIL, 2010f), ${ }^{15}$ está a previsão do recurso extraordinário. Sobre a suspensão de lei ou ato declarado inconstitucional pelo Senado Federal está no art. 52, inc. X da Constituição de 1988, reproduzindo as disposições previstas no art. 91, IV da Constituição de 1934, no art. 45, IV, da Constituição de 1967 e no art. 42, inc. VII da Emenda Constitucional n. 1 de 17 de outubro de 1969. Além disso, o art. 97 da Constituição de 1988 incorporou a disposição do art. 179 da Constituição de 1934, art. 200 da Constituição de 1946, art. 111 da Constituição de 1967 e art. 116 com a EC n. 1/69. ${ }^{16}$

Como relatado inicialmente, quanto à ação direta de inconstitucionalidade e à ação declaratória de constitucionalidade, elas foram reguladas pela Lei n. 9.868, de 10 de novembro de 1999; quanto à arguição de descumprimento de preceito fundamental, foi regulada pela Lei n. 9.882, de 3 de dezembro, 1999. Essas breves linhas buscaram apresentar como se dá o desenvolvimento histórico do controle de constitucionalidade no Brasil. Parte-se de um momento em que não havia um controle da constitucionalidade das normas por meio de um tribunal, passando pela criação de um tribunal inspirado no modelo norte-americano de controle de constitucionalidade das leis e, depois, pouco a pouco se importa a tradição de um modelo de controle abstrato do controle de constitucionalidade das leis.

A própria existência do controle de constitucionalidade funda-se, por outro lado, na tarefa de guardar a Constituição, colocada na Constituição Federal de 1988 no art. 102, caput. A expressão guarda da constituição, de outra maneira, remete ao debate realizado nos anos 30, entre Hans Kelsen (2007a) e Carl Schmitt (2007). Schmitt localiza no

${ }^{15}$ Art. 102. Compete ao Supremo Tribunal Federal, precipuamente, a guarda da Constituição, cabendo-Ihe: III - julgar, mediante recurso extraordinário, as causas decididas em única ou última instância, quando a decisão recorrida: a) contrariar dispositivo desta Constituição; b) declarar a inconstitucionalidade de tratado ou lei federal; c) julgar válida lei ou ato de governo local contestado em face desta Constituição. d) julgar válida lei local contestada em face de lei federal. Em relação à alínea "d", está prevista a possibilidade recurso extraordinário quando a decisão julgar válida lei local contestada em face de lei federal. Cabe salientar que essa alternativa foi incluída pela Emenda Constitucional n. 45, de 8 de dezembro de 2004.

${ }^{16}$ Foi modificado com a EC n. 7/77 (BRASIL, 2010e). 
monarca a ideia de órgão supremo do exercício do poder estatal, porém neutro e capaz de realizar sozinho o controle de constitucionalidade do exercício do poder estatal. Embasado na doutrina de Benjamin Constant, Kelsen aporta a crítica ao trabalho intelectual ideologizado a que estava a serviço a tese de Constant, que tentava aduzir acerca do poder ideologicamente neutro do monarca constitucional (HECK, 2008; KELSEN, 2007a). Questiona como poderia ser o monarca, ou seja, detentor de grande parcela do poder estatal porta-se como instância neutra no exercício desse poder e, ainda, a única com vocação para o controle de sua constitucionalidade (KELSEN, 2007a). Dentro do contexto da atmosfera política da monarquia, colocar o monarca como guardião da Constituição serviria plenamente para atingir seus objetivos políticos, em que pese isso não representar a tarefa do fazer uma teoria constitucional.

Para isso, Schmitt vai de encontro à ideia de uma jurisdição constitucional (HECK, 1995), ${ }^{17}$ isto é, da existência de um tribunal independente responsável pela garantia de constitucionalidade das leis. Um tribunal responsável por julgar a constitucionalidade de atos do parlamento, de regulamentos, de leis, de atos do governo, cassando tais atos em caso de sua anticonstitucionalidade (HECK, 2008). Segundo Kelsen, os argumentos de Schmitt partem da oposição fundamental entre a função de justiça e a função política "que particularmente a decisão sobre a constitucionalidade de leis e a anulação de leis anticonstitucionais é um ato 'político', do que é deduzido que tal atividade não é mais justiça” (HECK, 2008, p. 13). O político é visto na decisão (HECK, 1995, 2008) ${ }^{18}$ de conflitos de interesse,

17 A jurisdição constitucional pode ser definida no seu sentido material e no seu sentido formal. Em sentido formal, a jurisdição constitucional é definida a partir do órgão que a exerce. Em sentido material, a jurisdição constitucional é compreendida a partir do procedimento judiciário objetivando garantir diretamente a observância da Constituição (decisão de questões constitucionais por meio de um procedimento judicial). "Ocorre que, e já numa perspectiva moderna, não se trata tanto de decidir questões constitucionais, senão da garantir a observância da constituição e, isso (também a decisão), de forma direta (imediata)" (HECK, 1995, p. 23-24). Portanto, nas palavras de Heck, pode-se dizer que a jurisdição constitucional também possibilita englobar o desenvolvimento dos princípios constitucionais. (e nota n. 6)

18 Sobre o sentido da palavra decisão. 
logo, em toda a decisão judicial há um fator de exercício de poder, sendo mais forte o caráter político da justiça na medida em que é dada maior amplitude ao poder discricionário (ALEXY, 2000; HECK, 2002, 2008; MAURER, 2006). ${ }^{19}$ Ou seja, a função judicial tem o mesmo caráter político que a dação de leis, porque há uma transferência de poder de criação do direito, em conformidade com essa discricionariedade. Assim, a distinção entre o caráter político da dação de leis e a justiça é somente quantitativa (ALEXY, 2000; HECK, 2002, 2008; MAURER, 2006).

Essa relação que Schmitt traça como a justiça caracterizando como dação de leis, preservando uma ideia de relação entre ambas as funções de jurisdição e dação de leis, não deixa a jurisdição constitucional valer como justiça. Schmitt conclui que, para conflitos e questões altamente políticos, o guarda da constituição não deve ser um tribunal, pois a justiça seria posta em perigo em função de sua politização (KELSEN, 2007b). ${ }^{20}$ Com isso, Schmitt reforça a ideia do poder para o controle de constitucionalidade; em outras palavras, a guarda da Constituição deve ficar em mãos do presidente do Império.

Isso demonstra a necessidade (moderna) da rigorosíssima separação entre o conhecimento científico e sentenças de valor político. Também o próprio reforço ao que estava sustentado na Constituição de

19 Sobre a expressão "poder discricionário livre".

${ }^{20}$ Em consonância com a própria Constituição de Weimar (1919), que emprega o presidente do império como guarda da constituição. "Dizia o art. 48, da constituição do império de Weimar: (1) se um estado não cumpre os deveres que cabem a ele segundo a constituição do império ou as leis imperiais, pode o presidente imperial exortá-lo a isso com o auxílio do poder armado; (2) o presidente imperial pode, quando o império alemão a segurança e ordem pública é perturbada ou posta em perigo consideravelmente, tomar as medidas necessárias para o reestabelecimento da segurança e ordem pública, em caso necessário, intervir com o auxílio do poder armado. Para essa finalidade ele pode, temporariamente, deixar sem vigência, completamente ou em parte, os direitos fundamentais fixados nos artigos 114, 115, 117, 118, 123, 124, e 153; (3) de todas as medidas tomadas segundo a alínea 1 ou 2 deste artigo o presidente imperial tem de, sem demora, dar conhecimento ao parlamento imperial. Essas medidas devem, a pedido do parlamento imperial, ser deixadas sem vigência; (5) os detalhes determina uma lei imperial" (HECK, 2008, p. 25, grifo nosso). Sobre a legislação vigente em relação ao controle de constitucionalidade na Alemanha, ver Heck (2006).

Rev. Direito Econ. Socioambiental, Curitiba, v. 2, n. 1, p. 121-150, jan./jun. 2011 
Weimar tratou a própria história de mostrar o quão nefastos podem ser os resultados de tal esforço.

De outro lado, Kelsen posta-se como o defensor do Tribunal Constitucional como uma garantia constitucional. A jurisdição constitucional é vista como um sistema de medidas técnicas que garantem o exercício regular das funções estatais. Funções essas que, por sua vez, possuem um caráter jurídico, ou seja, consistem em atos jurídicos (normas jurídicas, atos de execução do direito criado). Em função disso, divide-se as funções estatais entre legislação e execução que, via de regra, opõe-se enquanto dois momentos distintos: criação/produção do direito versus aplicação do direito. Por isso, a execução regular, sua conformidade com a lei, são o objeto próprio desse controle (KELSEN, 2007b). É caractere do Estado moderno a criação de leis, de regulamentos, da Constituição como etapas de formação da vontade coletiva estatal. Como a Constituição regula a criação de leis e de regulamentos (em observância à Constituição), a aplicação do direito (sentença, ato administrativo), da mesma maneira, deve se dar em observação à Constituição. Figuras definidas assim por Kelsen (2007b): "estes, por sua vez, são aplicação do direito, se olharmos para cima, e criação do direito, se olharmos para baixo, isto é, no que concerne aos atos pelos quais são executados".

Do ato de criação até o ato de execução o direito não para de concretizar a Constituição, seja por normas jurídicas gerais (leis, regulamentos), seja por normas jurídicas individualizadas (sentença, ato administrativo), embora a liberdade de conformação do legislador em face da Constituição seja maior do que a reservada ao aplicador. Em outras palavras, a parte de aplicação aumenta enquanto a da livre criação diminui (KELSEN, 2007b). Dessa maneira, a produção do direito, numa ordem jurídica, deve se dar respeitando o grau inferior e uma reprodução do direito com respeito ao grau superior. Cada grau aplica uma ideia que Kelsen chama de regularidade, isto é, a correspondência de um grau inferior com um grau superior de uma ordem jurídica. Isso não se aplica apenas às normas jurídicas individuais, que dão execução às leis, aos regulamentos, mas também às normas jurídicas gerais (leis, regulamentos). 
Kelsen define a garantia da constitucionalidade das leis assim: "garantias da Constituição significam portanto garantias de regularidades das regras [graus jurídicos] imediatamente subordinadas à Constituição" (KELSEN, 2007b), próprio da ideia da estrutura hierárquica do direito.

Para garantir essa regularidade é preciso, no entanto, um órgão que fique responsável pelo julgamento. O órgão legislativo não é um órgão de aplicação do direito; considera-se, em realidade, um órgão de livre criação do direito (vinculado pela Constituição). Dessa forma, não é com o Parlamento que se conta para efetuar sua subordinação à Constituição. Há a necessidade de um órgão independente dele, diferente dele e de qualquer outra autoridade estatal, encarregado da anulação dos atos inconstitucionais, ou seja, um tribunal constitucional e, consequentemente, uma jurisdição constitucional. Esse tribunal, por outro lado, na lição de Kelsen, não está em oposição à soberania do Parlamento, isso porque a soberania não é do Parlamento, mas da ordem estatal (KELSEN, 2007b).

Assim, a Constituição é responsável por regular o processo legislativo, bem como as leis que regulam os procedimentos dos tribunais e das autoridades administrativas. Toda a regularidade, tanto do legislativo como da administração, tem uma vinculação à Constituição. De tal sorte que se conclui que o postulado da constitucionalidade das leis segue a mesma senda, teórica e tecnicamente, do que o postulado da legalidade da jurisdição e da legalidade da administração (KELSEN, 2007b). Cabe ainda tratar de outra objeção à existência de um tribunal responsável pelo controle de constitucionalidade, qual seja a violação do princípio da separação dos poderes. Sem dúvida a anulação (nulificação) de um ato legislativo por um órgão que não seja o legislativo será uma interferência de no Poder Legislativo. Contudo, essa questão ganha novos traços ao percebermos que o órgão a que "é confiada a anulação das leis inconstitucionais não exerce uma função verdadeiramente jurisdicional, mesmo se, com a independência de seus membros, é organizado em forma de tribunal" (KELSEN, 2007b). Anular a lei inconstitucional significa criar a lei com um sinal negativo, podendo isso ser interpretado como uma intromissão no Poder Legislativo. 
Por essa perspectiva, o fato do Parlamento poder elaborar leis, decretos e regulamentos, conjuntamente com o Poder Executivo, representaria a violação do princípio da separação dos poderes. Ou mesmo, ter-se-ia que se estudar os motivos políticos da elaboração dessa doutrina com vistas à manutenção do equilíbrio constitucional. Entretanto, basta se perceber que a manutenção do Tribunal Constitucional é melhor compreendida pela expressão "divisão dos poderes", isto é, a divisão de poderes entre órgão não pensando em isolá-los, mas, pelo contrário, para permitir um controle recíproco de uns sobre os outros. Isso impede a concentração de poder nas mãos de um só órgão, mas também garante a regularidade do funcionamento dos diferentes órgãos. Conclui, desta maneira, Kelsen (2007b, p. 152): "mas então a instituição da jurisdição constitucional não se acha em contradição com o princípio da separação dos poderes; ao contrário, é uma afirmação dele".

A partir desses argumentos se tem a justificação à existência do controle de constitucionalidade por um tribunal constitucional, construção teórica de Hans Kelsen, a qual é da década de 30. Com isso, buscou-se apresentar nesta parte a justificação da existência do controle de constitucionalidade e o desenvolvimento histórico dos instrumentos de controle de constitucionalidade nas diferentes Constituições brasileiras. No entanto, cada um desses instrumentos representa, por vezes, uma importação de um modelo de outra ordem constitucional sem a devida adequação, o que pode gerar problemas na sua aplicação.

\section{A importação de modelos, instrumentos de controle de constitucionalidade e sua adequação ao Brasil}

Nesse capítulo, procurar-se-á investigar a origem de cada modelo de controle de constitucionalidade das leis proposto na Constituição Federal, de igual modo em relação aos instrumentos de controle de constitucionalidade das leis. Constatando-se, muitas vezes, a inadequada importação e possíveis problemas que essa inadequação possa gerar, 
principalmente na utilização desses instrumentos de controle de constitucionalidade para fins políticos, tornando-os inócuos em face daquilo que se propugnavam originalmente, sendo, às vezes, apenas a expressão de uma cópia.

Não muito incomum no Brasil é a importação de modelos sem que seja proposta uma mínima adequação aos nossos parâmetros, ou melhor, faz-se uma adequação sem compreender o contexto em que estava inserto determinado modelo originalmente. Isso permite que um instrumento que é originalmente jurídico torne-se um instrumento de política e para a política, pois esse é um dos resultados nefastos quando há a importação sem a mínima a compreensão do fundo em que se deu o seu surgimento.

Essa crítica era feita por Kelsen ao responder Carl Schmitt, ao tratar sobre a questão de quem seria o guarda da constituição, abordada anteriormente, alegava que os argumentos de Schmitt tinham um fundo de política e não jurídico, pois retira de um órgão dotado de independência o exame da constitucionalidade de uma lei. Para Schmitt o caráter pluralista da jurisdição constitucional decorre como um processo, no qual se fazem valer "direitos subjetivos" na Constituição ou no poder estatal, sendo a decisão sobre a constitucionalidade um ato político, doutrina própria da ideologia monárquica (KELSEN, 2007a). Por vezes, incorremos nesse erro do fazer da ciência jurídica ao importarmos modelos que, por fim, acabam por ser instrumentalizados, perdendo o seu sentido e colocados à disposição de aspectos ideológicos.

Nada incomum se tratar de importações no Brasil. Importar modelos não é novidade para o Brasil e para os brasileiros; afinal, é corriqueiro se pensar que, se determinado modelo jurídico obteve resultado em um lugar "mais evoluído cultural e politicamente", nada mais natural que nós, como periféricos, terceiro mundo ou, eufemisticamente, país em desenvolvimento, copiarmos. Praticamos a mímica sem preocupação alguma em adequá-la à nossa realidade histórico-social: basta transladarmos algo que, supostamente, é sucesso em um país de primeiro mundo que funcionará aqui e daremos uma guinada no rumo da história rumo ao desenvolvimento, à redução da desigualdade, enfim, à realização de 
todos os direitos contidos na Constituição da República Federativa do Brasil de 1988.

Além disso, as tentativas de importação de modelos, como os de controle de constitucionalidade das leis, de apregoados sucesso devem ser permeado por uma adequação à cultura e à história do receptor, com a finalidade de evitar um total descompasso e aumentar significativamente as chances de êxito do modelo importado, como observam Badie e Hermet:

la actividad comparativa sería un mero pretexto si no considerada la profundidad histórica de cada objeto de estudio y si no identificara las fronteras y los lugares variables de lo político em cada lugar o época. Resultaría aún mas vana si el comparativista no se dedicar a ordenar y sistematizar los asuntos que le permiten observar las diferencias o semejanzas que servin para la comprensión de los fenómenos políticos. Para ello tiene que referirse a la acumulación del saber formal, es decir, a la teoría. Asimismo, conviene que gracias a ésta identifique sus instrumentos de conocimiento: es decir, las variables de su análisis, sin lo cual la comparación se queda en el terreno de la anécdota (BADIE; HERMET, 1993, p. 60). ${ }^{21}$

Pelo que foi referido, ilustra-se bem o cuidado que deve se ter ao importar modelos culturais e políticos. Não obstante, de tal cuidado não há precedentes na história brasileira. Nessa linha de ideias, em 1808 importa-se a Corte portuguesa para o Brasil (então colônia portuguesa). Em verdade, a Corte de Portugal foge para o Brasil acossada pela ameaça

21 "A atividade comparativa seria considerada um mero pretexto se não considerada a profundidade histórica de cada objeto de estudo e se não identificadas as fronteiras e os lugares variáveis do político em cada lugar ou época. Resultaria ainda mais vã se a pessoa encarregada de comparar não se dedica a ordenar e sistematizar os assuntos que lhe permitem observar as diferenças ou semelhanças que servem para compreensão dos fenômenos políticos. Para ele tem que se referir à acumulação do saber formal, ou seja, à teoria. Assim mesmo, convém que graças a esta identifique seus instrumentos de conhecimento: é dizer, as variáveis de sua análise, sem as quais a comparação fica no terreno da anedota" (tradução nossa). 
napoleônica, o que vai influenciar diretamente na formação do Estado brasileiro. Então, surge nosso primeiro problema: importa-se um Estado com predomínio da burocracia cuja aristocracia dependia cada vez mais do emprego público à sua sobrevivência.

Esse foi apenas um exemplo de importação de modelos ao Brasil, mas, claro, não é o único. Obviamente, isso não ocorre ao acaso em país cuja elite política é francamente unificada e profissionalizada - tais caracteres originam-se no Brasil-Colônia. Seria um tanto descabido admitir a possibilidade de importação ao natural.

Da mesma forma ocorre com o controle de constitucionalidade das leis no Brasil, que surge na Constituição de 1891, francamente inspirado na forma de controle jurisdicional implantado nos EUA, que tem como característica principal a possibilidade do exercício incidental, isto é, em uma ação qualquer, a titularidade para o exercício é difusa por todo o Judiciário, sendo a sentença declaratória de nulidade preexistente, com efeito, ex tunc (retroativo) e restrito inter partes (às partes). A compreensão desse modelo pode ser dada por Ruy Barbosa, que em petição examina a inconstitucionalidade de atos do Poder Executivo, acerca de reformas e demissões realizadas em 12 de abril de 1892, durante o estado de sítio, propondo a competência dos tribunais federais para examinarem acerca dos atos constitucionais e sua nulidade (BARBOSA, [18--?]). Isso porque o estado de sítio suspenderia unicamente as garantias limitadas pela Constituição ao definir esse recurso extraordinário, e não a Constituição. Dessa forma, as demissões e as reformas violariam a vitaliciedade de funções inamovíveis, exorbitando a previsão do direito constitucional (BARBOSA, [18--?]).

Com base nisso, Ruy Barbosa argue que os tribunais teriam autoridade para negar a execução do decreto e manter o direito dos indivíduos, quando fosse submetida a demanda à autoridade da justiça, sendo esse direito de examinar a inconstitucionalidade dos atos legislativos ou administrativos a base do regime constitucional (BARBOSA, [18--?]).

A Constituição de 1891, filha do direito norte-americano, nas palavras de Ruy Barbosa, importa esse modelo de controle de consti- 
tucionalidade, o qual prescrevia à Justiça Federal a realização desse controle. Isso com o cuidado tomado por Ruy Barbosa de apresentar as bases teóricas dessa forma de controle, como uma forma de limitação constitucional dos poderes, eivando do exercício a onipotência do chefe de Estado, chancelada pelo Parlamento (BARBOSA, [18--?]). Ou seja, ao tratar do controle de constitucionalidade, nos moldes apresentados pela Constituição de 1891, é preciso também que se compreenda quais as circunstâncias e referenciais teóricos, os quais permitem essa importação.

Eis então que surge o primeiro obstáculo à importação: o modelo jurídico utilizado no Brasil e o modelo jurídico adotado pelos Estados Unidos. O sistema jurídico dos EUA é o denominado common law, que atua com base na chamada doutrina do stare decisis (regra costumeira). O stare decisis (BARROS, 2001) ${ }^{22}$ indica que cada decisão da Suprema Corte norte-americana tem efeito vinculante. Assim, após decidir um recurso que julgue pela inconstitucionalidade, pela regra do stare decisis nenhum juiz ou tribunal inferior poderá voltar a aplicar a lei ou dispositivo, ele estará vinculado ao precedente. Ocorre que toda a tradição jurídica brasileira é ligada ao sistema jurídico do civil law - corroborado pelo período que antecede à República e pela formação dos juristas "brasileiros", via de regra, na Universidade de Coimbra em Portugal ${ }^{23}$ - que tem como premissa um direito codificado, escrito, sendo o juiz o responsável pela sua reprodução.

22 Não há uma rigidez absoluta, em função do stare decisis, como leciona o prof. Sérgio Resende de Barros (2001, p. 181): “o stare decisis é uma figura jurisprudencial, cuja locução completa é stare decisis et non quieta moverer. Ou seja, em princípio, o juiz deve ficar com os precedentes decididos e não alterar as decisões aquietadas. Contudo, por sua natureza jurisprudencial, esse princípio não impede mudar os precedentes, quando exigir a evolução do Direito. Por isso, não se deve entendêlo como vinculação inexorável. Não é esse o sentido do stare decisis norte-americano".

23 "Os juristas e magistrados exerceram um papel de grande importância na política e na administração portuguesa e posteriormente na brasileira. Tratava-se de uma elite sistematicamente treinada, sobretudo graças ao ensino de direito na Universidade de Coimbra, fundada em 1290. O direito ensinado em Coimbra era profundamente influenciado pela tradição romanista trazida de Bolonha. $O$ direito romano era particularmente adequado para justificar as pretensões de supremacia dos reis" (CARVALHO, 1996, p. 27, grifo nosso). 
Dessa forma, seria desnecessária a existência de um efeito vinculante, pois o legislador é o responsável pela criação, precipuamente, dos dispositivos normativos escritos. Para os americanos a soberania é inalienável, tendo os parlamentares apenas um poder subalterno e derivado, sem se olvidar do povo que é seu soberano, tendo como mandato a Constituição. Não se pode exceder pela Constituição, diferentemente, dos referenciais adotados pelo Brasil, à época franceses, os quais viam no parlamento a voz da nação e, desta forma, ilimitada a chamada vontade nacional. Portanto nada parecia limitar a autoridade legislativa das assembléias (BARBOSA, [18--?]).

Segundo o mesmo Ruy Barbosa, essa doutrina da onipotência das assembleias, a qual ele atribui aos franceses, contrariou o nosso direito escrito, no período, sendo esse o erro ao fazer a adequação no Brasil, tendo em vista que a contrariedade firmada ao controle de constitucionalidade (difuso) é baseada ainda na escola revolucionária francesa, em face da escola americana. Para uma escola, a assembleia é soberana por delegação do povo soberano, enquanto na outra a soberania não se delega, estando sempre nas mãos do povo. Isso porque "a soberania de uma assembleia seria forçosamente a negação e a ruína da soberania nacional" (BARBOSA, [18--?], p. 32). Se para uma o Poder Judiciário é dependente do Parlamento, para a outra ele é independente, sendo a Constituição quem domina as leis e os tribunais responsáveis por guardar a Constituição (BARBOSA, [18--?]).

Esse mimetismo que caracteriza o controle de constitucionalidade (difuso) na Constituição de 1891 perpassa todo o texto constitucional, devendo-se à contribuição de Ruy Barbosa ao texto constitucional. Nas palavras de Ruy Barbosa ([18--?], p. 32), "os autores de nossa Constituição, em cujo nome tenho algum direito de falar, não eram alunos políticos de ROUSSEAU e MABLY, como o nobre procurador da República: eram discípulos de MADISON e HAMILTON" (HAMILTON et al, 2003). ${ }^{24}$ Com isso, mostra os pressupostos teóricos que permitiriam a adequação

${ }^{24}$ Capítulo destinado a tratar da jurisdição na América. 
do modelo proposto de controle de constitucionalidade da Constituição de 1891, que entra em contradição com as leituras ainda francesas de uma Constituição que tinha por base o direito americano.

$\mathrm{Na}$ ocasião da feitura da Constituição de 1891, Ruy Barbosa foi responsável pela revisão do projeto, efetuando uma série de emendas. Enquanto nos EUA a doutrina do controle de constitucionalidade se dá com base em uma construção histórica, a qual deu novos caracteres ao direito inglês, no Brasil, diferentemente, se tinha um modelo e fica-se à mercê do bom senso dos aplicadores do direito para impor ao nosso sistema jurídico, já com pouca ou nenhuma identidade, um paradigma de controle de constitucionalidade das leis, totalmente diacrônico à nossa realidade histórico-social. Diante disso, fica-se ao alvedrio das tendências políticas, sem que, com isso, se dê importância aos referencias que servem de base à aplicação. Um instrumento que deveria ser uma das traves necessárias à própria manutenção e ao equilíbrio da separação dos poderes torna-se um centro que desequilibra, pois as referências adotadas diziam respeito aos argumentos políticos adotados pelos teóricos políticos franceses e não à Constituição americana, que serviu de inspiração à elaboração da Constituição de 1891.

O distanciamento do controle de constitucionalidade de leis brasileiro do controle norte-americano, em virtude de não existir o stare decisis no Brasil, fez com que o legislador constituinte, responsável pela elaboração do texto constitucional de 1934, aventasse a possibilidade da edição de resolução pelo Senado para ampliar erga omnes a decisão inter partes. Até então a decisão (formal e tecnicamente) do Supremo Tribunal Federal ficava restrita às partes contendoras, acerca da inconstitucionalidade de um ato normativo. Dessa forma, mesmo que o julgamento, em sede de recurso extraordinário, fosse pela inconstitucionalidade da lei, qualquer outro juiz ou tribunal poderia continuar a aplicá-la, exatamente pela ausência de um mecanismo que suprisse a ausência do stare decisis, fazendo com a decisão alcançasse todo o sistema jurídico.

Assim, em decorrência da Carta de 1934, o Supremo Tribunal Federal, depois que declarasse inconstitucional um dispositivo normativo, 
julgando um recurso extraordinário ou mesmo em julgamento originário, deveria comunicar ao Senado, ao qual competia suspender a execução da lei (BRASIL, 2010c) ${ }^{25}$ Com isso, o efeito que era inter partes tornar-se-ia erga omnes. Outro aspecto, mas ligado à Constituinte de 1934, é que foi apresentada uma proposta de criação de uma Corte Constitucional, inspirada no modelo austríaco. ${ }^{26}$ Entretanto, o projeto foi rejeitado sem maiores discussões pela Assembleia Constituinte. Ademais, surgiu na citada Constituição a representação interventiva, destinada ao controle de constitucionalidade da intervenção federal. Essa ação tinha como destino averiguar eventual afronta por meio de omissão ou ação contra os princípios fundamentais da ordem federativa (BRASIL, 2010c). ${ }^{27} \mathrm{O}$ procedimento da ação interventiva ficou a meio caminho entre o controle em tese e o controle concreto, e essa ação deveria ser proposta pelo procurador-geral da República.

Entre as Constituições de 1937 (em que pese o período autoritário) e de 1946 não houve alteração substancial no tocante ao controle de constitucionalidade da lei. A grande mudança viria com uma emenda à Constituição de 1946: trata-se da Emenda Constitucional n. 16, de 26 de novembro de 1965, pouco mais de um ano após o golpe militar. Tal emenda estabeleceu a representação contra inconstitucionalidade de lei ou ato de natureza normativa, federal ou estadual, encaminhada pelo

${ }^{25}$ Art 91 - Compete ao Senado Federal: IV - suspender a execução, no todo ou em parte, de qualquer lei ou ato, deliberação ou regulamento, quando hajam sido declarados inconstitucionais pelo Poder Judiciário.

${ }^{26}$ Conforme Mendes (1999, p. 27) "[...] a Corte Constitucional seria composta por nove membros escolhidos pelo Supremo Tribunal Federal (2), pelo Parlamento Nacional (2), pelo Presidente da República (2) e pela Ordem dos Advogados do Brasil (3). Deveriam ser eleitos, igualmente, nove suplentes. Este projeto confiava à Corte Constitucional o monopólio da censura das leis federais e estaduais. Assim, deveriam juízes ou Tribunais, em caso de inconstitucionalidade de uma lei, suspender os processos a eles afetos submeter à questão à Corte".

27 "Art 12 - A União não intervirá em negócios peculiares aos Estados, salvo: V - para assegurar a observância dos princípios constitucionais especificados nas letras $a$ a $h$, do art. 7o, n. I, e a execução das leis federais; § 2ㅇ - Ocorrendo o primeiro caso do n. V, a intervenção só se efetuará depois que a Corte Suprema, mediante provocação do Procurador-Geral da República, tomar conhecimento da lei que a tenha decretado e Ihe declarar a constitucionalidade".

Rev. Direito Econ. Socioambiental, Curitiba, v. 2, n. 1, p. 121-150, jan./jun. 2011 
procurador-geral da República. Novamente, longe de ser uma construção histórica, o formato concentrado do controle de constitucionalidade é instrumentalizado a não servir como obstáculo às atividades dos detentores do poder no regime ditatorial brasileiro. A Constituição de 1967 manteve o controle difuso e a representação interventiva. Por fim, a Constituição de 1988 sustenta a fórmula de controle misto de constitucionalidade, acrescentando a ação de inconstitucionalidade por omissão (originária do direito português) e a arguição de descumprimento de preceito fundamental (ADPF). Posteriormente, com a Emenda Constitucional n. 3/93, insere a ação declaratória de constitucionalidade.

Em que pese o controle concentrado de constitucionalidade ter inspiração no direito alemão e seu controle de constitucionalidade por meio do Tribunal Constitucional Federal, sendo a instância suprema em questões de direito federal e, com isso, "guarda da Constituição" (HECK, 1995, p. 87). As decisões do Tribunal Constitucional Federal são vinculativas para todos os tribunais e autoridades. Mais uma vez, fruto de importações que mais têm relação com a atenção a interesses políticos do que a questões jurídicas. Resultado dessas sucessivas importações será analisado por meio do controle constitucionalidade das políticas públicas.

\section{O controle de constitucionalidade de políticas públicas no Brasil}

Antes de se tratar do controle de políticas públicas no Brasil, é preciso compreender o que entendemos por políticas públicas. $\mathrm{O}$ ponto de partida adotado para a compreensão do esse conceito é a distinção realizada por Ronald Dworkin entre principle (princípio) e policy (políticas públicas). No seu Levando os direitos a sério (DWORKIN, 1977, 1995, 1999), ao tratar do modelo de regras I (model of rules I), abre subcapítulo destinado à distinção entre regras (rules), princípios (principles) e políticas públicas (policies). Assim, propõe-se a utilização do termo 'princípio', genericamente, para se referir a todo grupo de standards de conduta os quais não se adéque dentre as regras. Entretanto, é possível ser mais 
preciso e estabelecer a distinção entre princípios (principles) e políticas públicas (policies). Uma policy é entendida, por Dworkin, como um tipo de standard que estabelece um objetivo a ser alcançado. Em geral representa um melhoramento com caracteres sociais ou econômicos da comunidade. Princípio (principle), por sua vez, é um standard para ser observado, não porque sua observância represente um avanço ou um assegurar de uma situação política, social ou econômica desejada, mas por ser uma requisição de justiça ou equidade ou outra dimensão de moralidade (DWORKIN, 1977, 1999).

A política pública envolve toda a atividade estatal e não apenas o governo. Embora a política pública fique vinculada à Constituição e, consequentemente, às leis, aos regulamentos, às ordens advindas do Poder Legislativo há um espaço de conformação do governo, porém dentro do quadro normativo proposto pela Constituição (KELSEN, 2006). Logo a política pública é acompanhada de ações visando à realização de seus objetivos, não havendo a cisão entre diretriz e políticas públicas, uma vez que os objetivos estão insertos na política pública. Por fim, a política pública é um ato contínuo; isso significa dizer que não é apenas o ato que decreta uma lei (em conformidade com o estabelecido na Constituição Federal), mas também os atos subsequentes de implementação, execução e avaliação. Todos esses atos devem ser feitos em conformidade com a Constituição (THEODOULOU, 1995).

A figura das políticas públicas, no âmbito jurídico, surge como uma forma de concretização dos chamados direitos sociais, fruto de transformação do Estado liberal operada no século XX. Exigem-se prestações positivas do Estado com os chamados direitos sociais, apresentando-se no universo jurídico as políticas públicas. Por sua vez, as políticas públicas são definidas como standard que tem um objetivo social, econômico e político a ser atingido, fruto de uma conformação com o ordenamento jurídico-constitucional, ou seja, as políticas públicas implicam um dever de realização por parte de todos os poderes estatais e não apenas o Poder Executivo ou determinado governo, volta-se aos três a sua realização. Além disso, o processo de elaboração à execução de determinada política 
pública deverá respeitar, nessa perspectiva, o proposto pelo art. $3^{\circ}$ da Constituição Federal de 1988 (DWORKIN, 1999). Dessa forma, o Estado deve traçar uma série de medidas voltadas à coletividade (ordem pública), com o intuito de concretizar um direito voltado à comunidade.

Para se ter ideia, o fazer políticas públicas compreende uma série de estágios, resumidos da seguinte forma, inspirado em Theodoulou:

a) reconhecimento do problema e identificação das temáticas envolvidas naquela mesma área de atuação, em outros segmentos da administração pública, que possam contribuir para favorecer ou bloquear as soluções;

b) inserção do tema na agenda de ação do poder público;

c) formulação da política pública a ser concretizada, traduzindo-se concretamente as ações;

d) adoção da política pública, não só edição de ato, mobilização de órgãos e adoção de medidas necessárias;

e) implementação da política, envolvendo ações concretas por parte dos órgãos administrativos envolvidos;

f) análise da avaliação da política pública executada, à vista dos parâmetros que originalmente pautaram a sua concepção (THEODOULOU, 1995).

Dessa maneira, não se pode resumir as políticas públicas tão somente ao ato de implementação dessa política pública; há todo um processo que perpassa desde a escolha realizada pelo legislador, dentro do quadro normativo, até a formulação realizada pela administração pública, bem como a adoção de atos necessários à execução de determinada política pública. Da mesma forma, nesse processo, há o acompanhamento do Poder Judiciário, que verificará a adequação entre o standard preconizado como objetivo social, político ou econômico previsto na Constituição Federal e aquilo que o Estado propõe enquanto ação para realizar essa política pública. Isso, de certa maneira, permite afirmar que há a possibilidade de controle dessas políticas públicas por parte do Judiciário, 
principalmente ao verificar a constitucionalidade das políticas públicas. Uma margem de conformação ilimitada, novamente, autorizaria a confusão entre uma política partidária e uma política pública. Com isso, propõe-se a superação da confusão, do ponto de vista conceitual, apresentada anteriormente. Isto é, por um lado temos a liberdade de determinada agremiação política (partido político) eleger uma política - corporificada numa política de governo - e, ao ocupar o Executivo, buscar a sua adequação aos parâmetros constitucionais das políticas públicas; de outro, há o processo de criação, execução e implementação de políticas públicas que envolvem todo o Estado, ou seja, Poder Legislativo, Poder Executivo e Poder Judiciário, intentando a concretização do previsto na Constituição Federal (BUCCI, 1996, 2002, 2006). ${ }^{28}$

A possibilidade de submeter uma política pública ao controle judicial é, também, inquestionável, tendo em vista que a Constituição Federal garante no art. $5^{\circ}$, inc. XXXV (BRASIL, 2010f) ${ }^{29}$, o direito ameaçado ou lesado. Com isso, observe-se que o Poder Judiciário tutela as políticas públicas quando expressam um direito. Via de regra, o controle da constitucionalidade das políticas públicas dá-se por meio de ações

${ }^{28}$ No Brasil observam-se, principalmente, obras de autoria de Maria Paula Dallari Bucci tratando da temática ligada às políticas públicas como objeto de interesse ao direito administrativo. Parte do pressuposto de que as políticas públicas constituem temática oriunda da Ciência Política e da Administração, concluindo que é um campo de estudo que permite a abertura à interdisciplinariedade. Realiza distinções como de políticas públicas com suporte legal e políticas públicas com suporte constitucional - isso porque conceitualiza política pública como ação governamental. Incorre, novamente, no erro apontado anteriormente. Como visto, não é possível, sob a ótica do referencial teórico desta pesquisa, tratar de políticas públicas sem que se fale em previsão constitucional dessas políticas públicas. Do contrário, voltaremos à confusão entre políticas públicas e políticas partidárias, o que, do ponto de vista científico, serve somente à ideologização da ciência do direito.

${ }^{29}$ Art. 5o - Todos são iguais perante a lei, sem distinção de qualquer natureza, garantindo-se aos brasileiros e aos estrangeiros residentes no País a inviolabilidade do direito à vida, à liberdade, à igualdade, à segurança e à propriedade, nos termos seguintes: XXXV - a lei não excluirá da apreciação do Poder Judiciário lesão ou ameaça a direito.

Rev. Direito Econ. Socioambiental, Curitiba, v. 2, n. 1, p. 121-150, jan./jun. 2011 
coletivas com vistas a resolver conflitos que envolvam direitos consubstanciados em políticas públicas. ${ }^{30}$

Com base nessa distinção, pode-se compreender o que seria o conceito de políticas públicas, na obra de Ronald Dworkin, rompendo com alguns discursos políticos que permeavam as tratativas das políticas públicas. Entretanto, ao tratar da resposta ou de como os juízes devem responder, há uma substancial diferença nas respostas. Quando uma política pública é estabelecida pelo legislador, se dá com base em argumentos de política, isto é, um argumento que justifique uma decisão política demonstrando que essa decisão avança ou protege alguns objetivos coletivos da comunidade como um todo (DWORKIN, 1999).

Propõe-se a tese de que as decisões nos casos difíceis devem ser geradas caracteristicamente por princípios e não por decisões baseadas em argumentos de política. Em outras palavras, para que o juiz chegue à conclusão em determinado caso relacionado a políticas públicas, é preciso que haja argumentos que justifiquem a eleição daquele direito em detrimento de outro e, além disso, que essa decisão abra a perspectiva de sua universalização. Os juízes não devem fundar suas decisões em argumentos de política (DWORKIN, 1999). Para Dworkin, mesmo nos casos difíceis, os juízes devem apelar para os argumentos de princípio e não argumentos de política. Se os juízes fossem convocados a decidir conforme argumentos de política, o risco para a liberdade individual seria maior, certamente, do que se as decisões fossem em favor da proteção da moral e dos direitos políticos dos cidadãos de sua comunidade (DWORKIN, 1999). Assim, o risco que surge nesse caso é que a liberdade individual restaria erodida a um patamar maior do que o processo político, na primeira espécie de decisão. Na segunda hipótese, o risco é que os juízes sejam conservadores e se valham de seu poder menos do que poderiam, negando-se a reconhecer direitos individuais que o processo político haja consolidado no direito positivo (DWORKIN, 1999).

30 Sob a ótica processual, sem dúvida, a Lei n. 7.347, de 24 de julho de 1985, e Lei n. 8.078, de 1990, abriram grande espaço no processo civil brasileiro. 


\section{Considerações finais}

A pesquisa buscou apresentar, dentro das limitações de um trabalho deste fôlego, os caminhos e descaminhos do controle de constitucionalidade de leis no Brasil e as diferentes importações adotadas - ou seja, como um modelo de controle de constitucionalidade adotado de outro país sem que haja uma adequação do ponto de vista material pode ser prejudicial ao fazer da ciência jurídica. Em outras palavras, há apenas uma importação de um modelo, o qual tem êxito em outro país, em outro local, como se sua simples adoção pelo ordenamento jurídico brasileiro fosse suficiente para que houvesse uma transformação, no tocante ao controle de constitucionalidade. Tentou-se apresentar, com base principalmente nas considerações de Ruy Barbosa, a relação entre a adoção de um modelo de controle de constitucionalidade e sua adequação do ponto de vista doutrinário. E, além disso, as consequências dessas importações no exercício do controle de constitucionalidade, adotando-se como referências, no tocante ao controle de constitucionalidade das leis, o tema das políticas públicas.

Para isso, na primeira parte apresentou-se o desenvolvimento histórico, do ponto de vista normativo, em relação ao controle de constitucionalidade de leis no Brasil. Ademais, buscou-se demonstrar como se dão os debates em relação à guarda precípua da Constituição, ou seja, o debate entre Hans Kelsen e Carl Schmitt, principalmente a crítica que Kelsen faz em relação à politização do debate, por parte de Schmitt, também, como Schmitt instrumentaliza ou permite a instrumentalização da jurisdição constitucional. Kelsen posta-se como o defensor do Tribunal Constitucional como uma garantia constitucional. A jurisdição constitucional é vista como um sistema de medidas técnicas que garantem o exercício regular das funções estatais - funções essas que, por sua vez, possuem um caráter jurídico, ou seja, consistem em atos jurídicos (normas jurídicas, atos de execução do direito criado).

Após isso, tratou-se da questão ligada à importação de modelos de como - sob o viés social e cultural - a importação de algum modelo estrangeiro implica sucesso no Brasil. Em geral, demonstrou-se que essas 
importações sem uma necessária adequação, principalmente, sob o aspecto teórico podem gerar uma dessincronização entre dogmática e aplicação. Uma série de explicações culturais se sobrepõe, no caso do controle de constitucionalidade das leis, à crítica feita por Ruy Barbosa à exploração política do controle de constitucionalidade previsto na Constituição de 1891, em relação ao controle difuso de constitucionalidade. Fica evidenciada a crítica à leitura francesa, considerando os pressupostos teóricos, de um modelo importado do direito norte-americano, de como não há uma adequação. Além disso, pode-se notar como foi feita uma série de jogos políticos para de alguma forma adequar o controle de constitucionalidade, no tocante a interesses políticos, sendo solapado o debate de cariz jurídico, esse sim fundamental ao fazer da ciência jurídica.

Por fim, apresentou-se a discussão acerca do controle de constitucionalidade das políticas públicas no Brasil, bem como da própria importação do conceito de políticas públicas e de como esses descaminhos, em função dessas importações, saca um debate, o qual deveria ser realizado no bojo da ciência jurídica, para o campo político. Isso reflete diretamente no controle da constitucionalidade das políticas públicas, ficando-se as decisões, muitas vezes, ao alvedrio do juízo político do julgador do que a reconstrução, do ponto de vista argumentativo, da sua decisão, buscando a racionalização da decisão. Para tanto, baseou-se em alguns pressupostos teóricos tratados, principalmente, por Ronald Dworkin. Com isso, intentou-se apresentar sucintamente o controle de constitucionalidade de leis no Brasil com a Constituição de 1988, a importação de modelos de controle e como essa importação pode influenciar as decisões ou até mesmo o próprio caráter do tribunal responsável pela guarda da Constituição.

\section{Referências}

ALEXY, R. Vícios no exercício do poder discricionário. Revista dos Tribunais, v. 89, n. 779, p. 11-46, 2000. 
BADIE, B.; HERMET, G. Política comparada. México: Fondo de Cultura Económica, 1993.

BARBOSA, R. A Constituição e os actos inconstitucionais do Congresso e do Executivo ante a Justiça Federal. 2. ed. Rio de Janeiro: Atlântida, [18--?].

BARROS, S. R. de. O nó górdio do sistema misto. In: TAVARES, A. R.; ROTHENBURG, W. C. (Org.). Argüição de descumprimento de preceito fundamental: análises à luz da Lei n. 9.882/99. São Paulo: Atlas, 2001. p. 38-76.

BRASIL. Constituição (1824). Constituição: República Federativa do Brasil. Brasília, DF, Senado, 1824. Disponível em: <http://www.planalto.gov.br/ccivil_03/Constituicao/Constituiçao24.htm>. Acesso em: 5 jul. 2010a.

BRASIL. Constituição (1891). Constituição: República Federativa do Brasil. Brasília, DF, Senado, 1891. Disponível em: <http://www.planalto.gov.br/ccivil_03/constituicao/Constitui\%C3\%A7ao91.htm>. Acesso em: 5 jul. 2010b.

BRASIL. Constituição (1934). Constituição: República Federativa do Brasil. Brasília, DF, Senado, 1934. Disponível em: <http://www.planalto.gov.br/ccivil_03/constituicao/Constitui\%C3\%A7ao34.htm>. Acesso em: 5 jul. 2010c.

BRASIL. Constituição (1946). Constituição: República Federativa do Brasil. Brasília, DF, Senado, 1946. Disponível em: <http://www.planalto.gov.br/ccivil_03/constituicao/Constituiçao46.htm>. Acesso em: 6 jul. 2010d.

BRASIL. Constituição (1988). Emenda constitucional n. 1, de 17 de outubro de 1969. Disponível em: <http://www.planalto.gov.br/ccivil_03/constituicao/ Emendas/Emc_anterior1988/emc01-69.htm>. Acesso em: 6 jul. 2010e.

BRASIL. Constituição (1988). Constituição: República Federativa do Brasil. Brasília, DF, Senado, 1988. Disponível em: <http://www.planalto.gov.br/ccivil_03/constituicao/constituiçao.htm>. Acesso em: 7 jul. $2010 \mathrm{f}$.

BUCCI, M. P. D. As políticas públicas e o direito administrativo. Revista Trimestral de Direito Público, v. 13, p. 134-144, 1996. 
BUCCI, M. P. D. Direito administrativo e políticas públicas. São Paulo: Saraiva, 2002.

BUCCI, M. P. D. (Org.). Políticas públicas: reflexões sobre o conceito jurídico. São Paulo: Saraiva, 2006.

CARVALHO, J. M. de. A construção da ordem e teatro de sombras. Rio de Janeiro: Ed. UFRJ; Relume-Dumará, 1996.

DWORKIN, R. Is law a system of rules? In: DWORKIN, R. The philosophy of law. London: Oxford University Press, 1977. p. 43-44.

DWORKIN, R. Los derechos en serio. Barcelona: Ariel, 1995. p. 72.

DWORKIN, R. Taking rights seriously. Cambridge, Massachusetts: Harvard University Press, 1999. p. 22.

HAMiLtON, A. et al. The federalist papers. New York: Signet Classic, 2003.

HECK, L. A. O tribunal constitucional federal e o desenvolvimento dos princípios constitucionais: contributo para uma compreensão da jurisdição constitucional alemã. Porto Alegre: Sérgio Antonio Fabris, 1995.

HECK, L. A. O controle normativo no direito constitucional brasileiro. Revista dos Tribunais, v. 800, p. 57-64, jun. 2002.

HECK, L. A. Jurisdição constitucional e legislação pertinente no direito comparado. Porto Alegre: Livraria do Advogado, 2006.

HECK, L. A. Jurisdição constitucional: teoria da nulidade versus teoria da nulificabilidade das leis. Porto Alegre: Livraria do Advogado, 2008.

KELSEN, H. Teoria pura do direito. São Paulo: M. Fontes, 2006. p. 390.

KELSEN, H. Quem deve ser o guardião da Constituição? In: KELSEN, H. Jurisdição constitucional. São Paulo: M. Fontes, 2007a. p. 237-298.

KELSEN, H. A jurisdição constitucional: exposição de Hans Kelsen. In: KELSEN, H. Jurisdição constitucional. São Paulo: M. Fontes, 2007b. p. 121-186. 
MAURER, H. Direito administrativo geral. Barueri: Manole, 2006.

MENDES, G. F. Jurisdição constitucional: o controle abstrato de normas no Brasil e na Alemanha. 3. ed. São Paulo: Saraiva, 1999. p. 27.

SCHMITT, C. 0 guardião da Constituição. Belo Horizonte: Del Rey, 2007.

THEODOULOU, S.Z.Thenature of public policy.In:CAHN, M.A.; THEODOULOU, S. Z. Public Policy: the essential readings. New Jersey: Prentice-Hall, 1995. p. 2.

Recebido: 06/05/2011

Received: 05/06/2011

Aprovado: 20/05/2011

Approved: 05/20/2011 